\title{
Helper T-Lymphocyte-Related Chemokines in Healthy Newborns
}

\author{
TING-FAN LEUNG, PAK-CHEUNG NG, WING-HUNG TAM, CHUNG-YI LI, ERIC WONG, \\ TERENCE P.Y. MA, CHRISTOPHER W.K. LAM, AND TAI-FAI FOK
}

Departments of Pediatrics [T.-F.L., P.-C.N., C.-Y.L., T.P.Y.M., T.-F.F.], Obstetrics and Gynecology [W.-H.T.], and Chemical Pathology [C.W.K.L.], and Center for Clinical Trials and Epidemiological Research [E.W.], The Chinese University of Hong Kong, Prince of Wales Hospital, Hong Kong.

\begin{abstract}
Atopic disease is characterized by an imbalance in cytokines secreted from Th1 and Th2 lymphocytes. The association between atopy and serum levels of atopy-related chemokines in umbilical cord blood (UCB) has not been evaluated. This study formulates the reference ranges of thymus and activationregulated chemokine (TARC), macrophage-derived chemokine (MDC), eotaxin (EOX), monocyte chemotactic protein 1 (MCP1 ), and interferon- $\gamma$-inducible protein 10 (IP-10) in UCB of term neonates and investigates the relation between these chemokines and the development of atopy during infancy. The concentrations of total $\operatorname{IgE}$ and chemokines in UCB serum were measured by microparticle immunoassay and sandwich enzyme immunoassay, respectively. A total of 124 singleton healthy newborns were investigated. Fifty-three (43\%) infants had family history of allergic diseases, and $26(21 \%)$ had increased serum total $\operatorname{IgE}$ concentrations. The median (interquartile range) serum TARC, MDC, EOX, MCP-1, and IP-10 concentrations, in $\mathrm{pg} / \mathrm{mL}$, were 425 (300-639), 786 (561-1050), 36 (28-45), 156 (116-205), and 38 (29-49), respectively. Multiparity was associated with increased serum MDC ( $p=0.017)$. Serum chemokine concen-
\end{abstract}

\section{ABSTRACT}

trations were not associated with total IgE levels or family history of allergies. The median (interquartile range) serum MDC concentrations in newborns who developed wheezing during infancy and those without wheezing were $1259 \mathrm{pg} / \mathrm{mL}(945-$ $1523)$ and $782 \mathrm{pg} / \mathrm{mL}(551-992)$, respectively $(p=0.010)$. This study provides reference ranges of Th-specific chemokines in UCB serum of singleton term neonates. Increased serum MDC concentrations at birth are associated with the occurrence of wheezing during infancy. (Pediatr Res 55: 334-338, 2004)

\section{Abbreviations}

BRD, bronchopulmonary dysplasia

EOX, eotaxin

IFN- $\boldsymbol{\gamma}$, interferon- $\boldsymbol{\gamma}$

IP-10, interferon- $\gamma$-inducible protein 10

IQR, interquartile range

MCP-1, monocyte chemotactic protein 1

MDC, macrophage-derived chemokine

TARC, thymus and activation-regulated chemokine

UCB, umbilical cord blood
Asthma and atopy are characterized by an overproduction of type-2 helper T (Th2) lymphocyte-related cytokines such as IL-4, IL-5, and IL-13 and a relative deficiency of Th1-related interferon- $\gamma($ IFN- $\gamma$ ), IL-2, and IL-12 (1). Chemokines are a family of cytokines involved in the trafficking of leukocytes to the site of inflammation (2). Chemokines have been classified into four groups $-\mathrm{C}, \mathrm{C}-\mathrm{C}, \mathrm{C}-\mathrm{X}-\mathrm{C}$ and $\mathrm{C}-\mathrm{X}_{3}-\mathrm{C}-$ depending on the number and spacing of conserved cysteines. Recently, it was suggested that the expression of some chemokines could be preferentially associated with a Th1 or a Th2 immune response. The differential expression of chemokine receptors may dictate the actions of chemokines and their involvement in

Received February 11, 2003; accepted July 20, 2003.

Correspondence: Ting-fan Leung, Department of Pediatrics, 6/F, Clinical Sciences Building, Prince of Wales Hospital, Shatin, Hong Kong; e-mail: leung2142@cuhk.edu.hk Supported by a Direct Grant for Research from The Chinese University of Hong Kong.

DOI: 10.1203/01.PDR.0000102456.03407.84 mechanisms of polarized Th1- and Th2-mediated immune responses $(3,4)$. The expression of CC chemokines, such as eotaxin (EOX) $(5,6)$, thymus and activation-regulated chemokine (TARC) $(7,8)$, macrophage-derived chemokine (MDC) $(9,10)$, and monocyte chemotactic protein 1 (MCP-1) $(11,12)$, has been studied mainly in Th2-mediated allergic diseases. These molecules are chemotactic for eosinophils, lymphocytes, and monocytes $(2,13)$. In contrast, the $\mathrm{C}-\mathrm{X}-\mathrm{C}$ chemokine IFN- $\gamma$-inducible protein 10 (IP-10) is chemotactic for neutrophils and lymphocytes (14). The expression of IP-10 is upregulated in many Th1-type inflammatory diseases (6). In view of the important roles that these mediators play in maintaining the Th1/Th2 balance, the serum concentrations of these atopyrelated chemokines at birth may be associated with other possible "predictors" of atopy (e.g. serum total IgE) or family history of allergic diseases. The aim of this study was to describe the reference ranges of the above chemokines in umbilical cord blood (UCB) serum of healthy singleton term 
newborns and to investigate the association between family history of allergies and the development of atopic disorders during infancy in these newborns and concentrations of various chemokines in newborn infants.

\section{METHODS}

Study population. Singleton infants who were delivered between 37 and 42 wk of gestation at the Prince of Wales Hospital, Hong Kong, were eligible. Mothers were required to give informed consent for UCB collection during the intrapartum period. This study excluded pregnant women with gestational diabetes, preeclampsia, and intrauterine infection (rupture of membranes $\geq 24 \mathrm{~h}$ together with maternal fever $\geq 38^{\circ} \mathrm{C}$, foul-smelling or meconium-stained amniotic fluid) and those who smoke. Newborns with major or lethal congenital malformation and those with suspected early-onset clinical sepsis were also excluded. The presence of a family history of physician-diagnosed asthma, allergic rhinitis, hay fever, or atopic dermatitis in the first-degree relatives of recruited subjects was also recorded. A telephone interview was conducted with caregivers to document the development of atopic disorders in recruited newborns when they were 12 to 15 mo of age. The questionnaire for this follow-up assessment, modified from that published by the Tucson group (15), is provided in Appendix 1. The Clinical Research Ethics Committee of our university approved this study.

Serum total IgE and IgA concentrations. Clotted blood was collected under aseptic technique from umbilical vein before placental separation, and the blood samples were centrifuged at $4^{\circ} \mathrm{C}$ and $1800 \times g$ for $10 \mathrm{~min}$. Serum was extracted and stored at $-70^{\circ} \mathrm{C}$ until analysis. Serum IgA concentration was measured by rate turbidimetry using the Hitachi 917 analyzer (Roche Diagnostics GmbH, Mannheim, Germany) and was used as marker for maternal blood contamination (16). The sensitivity of this assay is $0.05 \mathrm{~g} / \mathrm{L}$ with a precision of $3.2 \%$. Serum total $\mathrm{IgE}$ concentrations were measured by micropar- ticle immunoassay (IMx analyzer; Abbott Laboratories, Abbott Park, IL, U.S.A.). The sensitivity of this method in detecting serum IgE was $0.048 \mathrm{kIU} / \mathrm{L}$.

Serum chemokine concentrations. Serum samples stored at $-70^{\circ} \mathrm{C}$ were analyzed for chemokine concentrations in batches. We used 96-well polystyrene microplates coated separately with murine MAb against human chemokines. The serum levels of EOX (Biosource International, Camarillo, CA, U.S.A.) as well as TARC, MDC, MCP-1, and IP-10 (Quantikine ELISA; R \& D Systems, Minneapolis, MN, U.S.A.) were measured in duplicate by sandwich enzyme immunoassay according to manufacturers' instructions, and mean values were recorded. The sensitivities of this method in measuring these chemokines were $2.2,7.0,62.5,5.0$, and $1.67 \mathrm{pg} / \mathrm{mL}$, respectively.

Statistical analysis. Results are presented as median and interquartile range (IQR). The relation between demographic data and serum total $\mathrm{IgE}$ and chemokine levels in different groups was analyzed using Mann-Whitney $U$ test or KruskalWallis test where appropriate. Pearson and Spearman coefficients were used to analyze the correlation for parametric and nonparametric data, respectively. Serum IgE levels were presented after logarithmic transformation $\left(\mathrm{IgE}_{\mathrm{log}}\right)$, and the analysis of this variable was carried out with UCB IgE concentration dichotomized at a cut-off value of $0.5 \mathrm{kIU} / \mathrm{L}$ (17). The proportion of newborns with increased $(\geq 0.5 \mathrm{kIU} / \mathrm{L})$ and normal $(<0.5 \mathrm{kIU} / \mathrm{L}) \mathrm{IgE}$ for each of the allergic family history and presence of atopic disorders at telephone follow-up was compared using $\chi^{2}$ test or Fisher exact test where appropriate. The differences in serum total IgE and chemokine levels in infants with and without atopic disorders at 12 to $15 \mathrm{mo}$ of age were compared using Mann-Whitney $U$ test. All comparisons were made two-sided using SPSS 11.0 for Windows (Chicago, IL, U.S.A.). $P<0.05$ was considered statistically significant. Last, the percentiles of serum chemokine concentrations in

Table 1. The demographic data and information on atopy in our 124 singleton newborns

\begin{tabular}{|c|c|c|c|}
\hline Characteristics* & $\begin{array}{c}\text { FH of allergic } \\
\text { diseases }(n=53)\end{array}$ & $\begin{array}{l}\text { No FH of allergic } \\
\text { diseases }(n=71)\end{array}$ & $p$ values \\
\hline \multicolumn{4}{|l|}{ Demographics of newborns } \\
\hline Gestational age (wk) & $39.6 \pm 1.2$ & $39.9 \pm 1.4$ & 0.178 \\
\hline Birth weight (kg) & $3.20 \pm 0.33$ & $3.34 \pm 0.43$ & 0.043 \\
\hline Maternal age at delivery (y) & $29.3 \pm 4.9$ & $28.7 \pm 4.9$ & 0.501 \\
\hline Parity $(1: 2: 3$ or more $)$ & $35: 15: 3$ & $45: 21: 5$ & 0.613 \\
\hline \multicolumn{4}{|l|}{ Family history of allergic diseases } \\
\hline Father $[n(\%)]$ & $27(51)$ & 0 & NA \\
\hline Mother $[n(\%)]$ & $29(55)$ & 0 & NA \\
\hline Siblings $[n(\%)] \dagger$ & $9(50)$ & 0 & NA \\
\hline Serum $\operatorname{IgE}_{\log }(\mathrm{kIU} / \mathrm{L})$ & $-0.70 \pm 0.48$ & $-0.63 \pm 0.50$ & 0.433 \\
\hline $\begin{array}{l}\text { Number of newborns with serum total } \\
\text { IgE level } \geq 0.5 \mathrm{kIU} / \mathrm{L}[n(\%)]\end{array}$ & $10(19)$ & $16(23)$ & 0.620 \\
\hline
\end{tabular}

* Expressed as mean \pm SD unless otherwise stated.

$\dagger$ Eighteen newborns with and 26 newborns without allergic siblings among a total of 44 neonates with one or more siblings.

AVD, assisted vaginal delivery (forceps or vacuum extraction); CS, caesarean section; FH, family history; NA, not applicable; SVD, spontaneous vaginal delivery. 
Table 2. The reference ranges of UCB serum chemokine concentrations in singleton term newborns

\begin{tabular}{|c|c|c|c|c|c|}
\hline \multirow[b]{2}{*}{ Data range } & \multicolumn{5}{|c|}{ Serum concentrations $(\mathrm{pg} / \mathrm{mL})$} \\
\hline & TARC & MDC & EOX & MCP-1 & IP-10 \\
\hline 5th percentile & 164 & 409 & 22 & 86 & 16 \\
\hline 25 th percentile & 300 & 561 & 28 & 116 & 29 \\
\hline 50th percentile & 425 & 786 & 36 & 156 & 38 \\
\hline 75th percentile & 639 & 1050 & 45 & 205 & 49 \\
\hline
\end{tabular}

UCB were derived by mean \pm SD following logarithmic transformation of these markers to achieve normal distribution.

\section{RESULTS}

Demographic data of subjects. The clinical characteristics of recruited subjects are summarized in Table 1. Fifty-three $(43 \%)$ newborns had at least one first-degree relative who had allergic diseases. Serum IgA concentrations were $<0.05 \mathrm{~g} / \mathrm{L}$ for all samples. $\mathrm{IgE}_{\mathrm{log}}$ did not differ in subjects with or without the allergic family history. However, the median $\operatorname{IgE}_{\log }$ was higher in newborns with atopic siblings $(-0.96 \mathrm{kIU} / \mathrm{L}$ versus $-0.62 \mathrm{kIU} / \mathrm{L} ; p=0.02$ ). The proportion of newborns who had allergic family members also did not differ between those with increased or normal and undetectable IgE levels in UCB serum (results not shown).

Serum chemokine concentrations in neonates. Table 2 shows the percentile values of serum TARC, MDC, EOX, MCP-1, and IP-10 concentrations at birth. Serum MDC levels increased significantly with maternal multiparity, the median (IQR) being $1233 \mathrm{pg} / \mathrm{mL}(902-1465)$ for parity $\geq 3$ and 781 $\mathrm{pg} / \mathrm{mL}(555-1016)$ for parity $\leq 2(p=0.017)$. The median serum IP-10 concentrations were also significantly higher in those who were born by spontaneous vaginal delivery ( 42 $\mathrm{pg} / \mathrm{mL})$ compared with assisted vaginal delivery $(30 \mathrm{pg} / \mathrm{mL})$ or caesarean section ( $36 \mathrm{pg} / \mathrm{mL} ; p=0.018)$. The other demographic factors were not significantly associated with serum chemokine levels. Significant correlation was found between serum concentrations of TARC and MDC $(r=0.506, p<$ $0.0001)$, TARC and EOX $(r=0.339, p=0.0001)$, MDC and MCP-1 $(r=-0.214, p=0.017)$, and EOX and MCP-1 $(r=$ $0.287, p=0.001)$. No significant correlation was found between serum $\mathrm{IgE}_{\log }$ and levels of serum chemokines.

Atopy and chemokine levels in UCB. Serum EOX concentration was significantly lower in subjects whose father had allergic diseases [median (IQR): $29 \mathrm{pg} / \mathrm{mL}(26-38)$ versus 37 $\mathrm{pg} / \mathrm{mL}(29-46) ; p=0.047]$. Serum chemokine concentrations were otherwise not associated with the presence of allergies in mothers or siblings of the newborns or whether they had increased serum IgE concentrations.

UCB chemokines in relation to atopy development. Ninetysix (77\%; from 49 boys and 47 girls) caregivers of the infants could be contacted for the telephone interview. Table 3 summarizes the development of atopic disorders in infants with increased or normal serum total IgE. When total $\operatorname{IgE}$ and chemokines were analyzed between infants with and without atopic phenotypes on follow-up, we found that serum MDC concentrations in UCB were significantly higher in infants with "wheeze ever" compared with those without [median (IQR): $1259 \mathrm{pg} / \mathrm{mL}$ (945-1523) versus $782 \mathrm{pg} / \mathrm{mL}$ (551-992); $p=$ $0.010]$. Conversely, $\operatorname{IgE}_{\log }$ in UCB was lower in those with "MD allergic rhinitis" [median (IQR): $-1.05 \mathrm{kIU} / \mathrm{L}(-1.19$ to $-0.95)$ versus $-0.74 \mathrm{kIU} / \mathrm{L}(-1.01$ to -0.44$) ; p=0.019]$.

\section{DISCUSSION}

This study provides reference ranges of serum TARC, MDC, EOX, MCP-1, and IP-10 concentrations in UCB from healthy singleton term newborns. A number of demographic factors affect serum chemokine levels. These markers are in general not related to the presence of allergic diseases in the family members of our subjects with the exception of paternal atopy. In this study of Chinese newborns, serum total IgE levels did not differ between those with and without family history of allergies and also are not associated with serum chemokine concentrations. Increased serum MDC concentrations in UCB are found in newborns who had wheezing during infancy, whereas lower serum total $\mathrm{IgE}$ concentrations are present in UCB from infants being labeled as having "allergic rhinitis" at 12 to 15 mo of age.

Sullivan et al. (18) recently published the first report on the concentrations of circulating chemokines in neonates. The authors found that serum levels of neutrophil-specific $\alpha$-chemokines and eosinophil-, basophil-, and monocyte-specific $\beta$-chemokines from 50 preterm infants were either similar to or

Table 3. The spectrum of atopic disorders that developed in the 96 infants whose caregivers participated in the follow-up interview

\begin{tabular}{|c|c|c|c|}
\hline Phenotypes*† & $\begin{array}{c}\text { Serum total } \\
\mathrm{IgE} \geq 0.5 \mathrm{kIU} / \mathrm{L} \\
(n=17)\end{array}$ & $\begin{array}{c}\text { Serum total } \\
\mathrm{IgE}<0.5 \mathrm{kIU} / \mathrm{L} \\
(n=79)\end{array}$ & $p$ values \\
\hline Wheeze ever & 0 & $7(9)$ & 0.346 \\
\hline $\begin{array}{l}\text { Cough apart from } \\
\text { cold }\end{array}$ & $3(18)$ & $13(16)$ & 1.000 \\
\hline MD asthma & $2(12)$ & $12(15)$ & 1.000 \\
\hline $\begin{array}{l}\text { Nasal symptoms apart } \\
\text { from cold }\end{array}$ & $7(41)$ & $37(47)$ & 0.671 \\
\hline MD allergic rhinitis & 0 & $6(8)$ & 0.587 \\
\hline Itchy flexural rash & $2(12)$ & $7(9)$ & 0.658 \\
\hline MD atopic dermatitis & $2(12)$ & $10(13)$ & 1.000 \\
\hline $\begin{array}{l}\text { MD asthma, allergic } \\
\text { rhinitis, or atopic } \\
\text { dermatitis }\end{array}$ & $3(18)$ & $22(28)$ & 0.546 \\
\hline
\end{tabular}

* Expressed as number (\%) unless otherwise stated.

$\dagger$ Refer to Appendix 1 for meanings of the abbreviations.

$\$$ Analyzed by $\chi^{2}$ or Fisher exact test. 
higher than those measured in 50 term neonates, suggesting that newborn infants can elicit effective inflammatory responses via the chemokine network. Among the chemokines studied, the mean serum EOX concentration was found to be $80 \mathrm{pg} / \mathrm{mL}$ and was higher than our result (median, $36 \mathrm{pg} / \mathrm{mL}$ ). One possible explanation is that we have excluded neonates who were born to mothers with stressful medical diseases such as preeclampsia, which might induce the activation of leukocytes and chemokine cascades in the fetal circulation (19). Our study also excluded neonates with clinical sepsis, which could also increase serum chemokine levels (20-22).

TARC acts on the chemokine receptor CCR4 (7), and in vitro studies showed that TARC could induce selective migration of Th2 lymphocytes $(3,7,13)$. The expression of CCR4 on Th2 lymphocytes and CCR4-specific ligand TARC was upregulated on airway epithelial cells from patients with asthma after allergen challenge (8). TARC has also been implicated in the pathogenesis of allergic rhinitis and atopic dermatitis (2325 ). Our study group recently found that plasma TARC levels were elevated in children with chronic stable asthma, which could be lowered by the use of inhaled corticosteroids. This inflammatory marker also correlated with spirometric indices in children with asthma (26). TARC, as well as MDC and EOX, also correlated significantly with the severity of atopic dermatitis in young Chinese children (27). The present study found the median (IQR) serum TARC concentration in UCB to be $425 \mathrm{pg} / \mathrm{mL}$ (300-639), which was higher than the corresponding values that we have found for 12 adult control subjects (median: $253 \mathrm{pg} / \mathrm{mL}$; IQR: 176-319 pg/mL; unpublished data). Our study support that TARC-mediated chemotaxis of Th2 cells to sites of allergic inflammation is operational even in term newborns. Further studies with serial measurements are necessary to characterize the maturational changes of serum chemokine levels during infancy and childhood.

All five atopy-related chemokines studied could be detected in appreciable quantities in UCB from healthy term neonates. This finding supports that newborn infants theoretically are capable of mounting adequate chemotactic responses for leukocytes in acute and chronic inflammatory conditions. The present study has tried to establish the relation between serum chemokines at birth and the development of atopic disorders during infancy. Newborns who developed "wheeze ever" during infancy had higher serum MDC concentrations at birth. The other atopy-related chemokines were not associated with the occurrence of any atopy phenotype during infancy. The main drawback, however, was that our research team could not contact the caregivers of $23 \%$ of our recruited newborns for telephone follow-up because many families moved back to the Chinese Mainland after birth of the infants. Complete follow-up of a larger birth cohort is necessary to assess accurately whether chemokines in UCB could be used to predict the development of atopic disorders during infancy.

Chemokines may be involved in the pathogenesis of other neonatal diseases in addition to allergies. Both MCP-1 and IP-10 were increased in the early phase in the lungs of newborn mice during acute hyperoxia or after inhalation of endotoxin $(28,29)$. Eosinophil infiltration could be found in lung tissues obtained from premature infants who developed bronchopulmonary dysplasia (BPD), and eosinophil cationic protein was also detected in tracheal aspirates from these patients $(30,31)$. These observations are similar to those seen in patients with asthma. A significant proportion of preterm infants with BPD developed asthma-like bronchoconstriction when they grew older $(32,33)$. In view of the linkage between asthma and TARC and MDC $(8-10,26)$, it is possible that these Th2specific chemokines are also involved in the development of BPD. However, there has not been any evidence on the pathogenic roles of chemokines in neonatal respiratory diseases. Our results on UCB chemokine concentrations in healthy newborns may serve as a reference to compare changes in serum chemokine levels associated with inflammatory diseases in neonates. Further studies are needed to establish the reference ranges of chemokines in preterm neonates and also to investigate whether serum chemokine levels in newborns are useful in predicting the outcomes of potentially serious diseases such as BPD and sepsis.

\section{CONCLUSION}

In conclusion, this study describes the reference ranges of serum concentrations of Th-specific chemokines in UCB of term neonates. In newborn infants, serum concentrations of our five atopy-related chemokines are in general not related to family history of allergic diseases. Newborns who experienced wheezing during infancy had increased serum MDC concentrations at birth.

\section{APPENDIX 1: DETAILS OF THE QUESTIONNAIRE USED FOR TELEPHONE INTERVIEW}

1. Has your child ever had attacks of wheezing? (Wheeze ever)

2. Does your child usually have a cough apart from colds? (Cough apart from cold)

3. Has any doctor told you that your child has asthma or bronchitis? (MD asthma)

4. Does your child have nasal discharge or sneezing apart from cold since birth? (Nasal symptoms apart from cold)

5. Has any doctor told you that your child has allergic rhinitis? (MD allergic rhinitis)

6. Has your child ever had persistent ( $>4 \mathrm{wk}$ ) itchy flexural rash? (Itchy flexural rash)

7. Has any doctor told you that your child has atopic dermatitis? (MD atopic dermatitis)

Acknowledgment. We thank midwives who work in the obstetric unit for help with UCB collection.

\section{REFERENCES}

1. Romagnani S 2000 The role of lymphocytes in allergic disease. J Allergy Clin Immunol 105:399-408

2. Baggiolini M, Dewald B, Moser B 1997 Human chemokines: an update. Ann Rev Immunol 15:675-705

3. Bonecchi R, Bianchi G, Bordignon PP, D’Ambrosio D, Lang R, Borsatti A, Sozzani S, Allavena P, Gray PA, Mantovani A, Sinigaglia F 1998 Differential expression of chemokine receptors and chemotactic responsiveness of type $1 \mathrm{~T}$ helper cells (Th1s) and Th2s. J Exp Med 187:129-134 
4. Sallusto F, Lenig D, Mackay CR, Lanzavecchia A 1998 Flexible programs of chemokine receptor expression on human polarized T helper 1 and 2 lymphocytes. J Exp Med 187:875-883

5. Mochizuki M, Bartels J, Mallet AI, Christophers E, Schroder JM 1998 IL-4 induces eotaxin: a possible mechanism of selective eosinophil recruitment in helminthic infection and atopy. J Immunol 160:60-68

6. Miotto D, Christodoulopoulos P, Olivenstein R, Taha R, Cameron L, Tsicopoulos A, Tonnel AB, Fahy O, Lafitte JJ, Luster AD, Wallaert B, Mapp CE, Hamid Q 200 Expression of IFN- $\gamma$-inducible protein; monocyte chemotactic proteins 1,3 , and 4; and eotaxin in $\mathrm{T}_{\mathrm{H}} 1$ - and $\mathrm{T}_{\mathrm{H}} 2$-mediated lung diseases. J Allergy Clin Immunol $107: 664-670$

7. Imai T, Baba M, Nishimura M, Kakizaki M, Takagi S, Yoshie O 1997 The T cell-directed CC chemokine TARC is a highly specific biological ligand for CC chemokine receptor 4. J Biol Chem 272:15036-15042

8. Panina-Bordignon P, Papi A, Mariani M, Di Lucia P, Casoni G, Bellettato C, Buonsanti C, Miotto D, Mapp C, Villa A, Arrigoni G, Fabbri LM, Sinigaglia F 2001 The C-C chemokine receptors CCR4 and CCR 8 identify airway T cells of allergenchallenged atopic asthmatics. J Clin Invest 107:1357-1364

9. Andrew DP, Chang MS, McNinch J, Wathen ST, Rihanek M, Tseng J, Spellberg JP, Elias CG 3rd 1998 STCP-1 (MDC) CC chemokine acts specifically on chronically activated Th2 lymphocytes and is produced by monocytes on stimulation with Th2 cytokines IL-4 and IL-13. J Immunol 161:5027-5038

10. Bonecchi R, Sozzani S, Stine JT, Luini W, D’Amico G, Allavena P, Chantry D, Mantovani A 1998 Divergent effects of interleukin-4 and interferon-gamma on macrophage-derived chemokine production: an amplification circuit of polarized $\mathrm{T}$ helper 2 responses. Blood 92:2668-2671

11. Car BD, Meloni F, Luisetti F, Semenzato F, Gialdroni-Grassi G, Walz A 1994 Elevated IL-8 and MCP-1 in the bronchoalveolar lavage fluid of patients with idiopathic pulmonary fibrosis and pulmonary sarcoidosis. Am J Respir Crit Care Med 149:655-659

12. Chensue SW, Warmington KS, Ruth JH, Sanghi PS, Lincoln P, Kunkel SL 1996 Role of monocyte chemotactic protein-1 (MCP-1) in Th1 (mycobacterial) and Th2 (schistosomal) antigen-induced granuloma formation: relationship to local inflammation, Th cell expression, and IL-12 production. J Immunol 157:4602-4608

13. Imai $T$, Nagira $M$, Takagi S, Kakizaki M, Nishimura M, Wang J, Gray PW, Matsushima K, Yoshie O 1999 Selective recruitment of CCR4-bearing Th2 cells toward antigen-presenting cells by the $\mathrm{CC}$ chemokines thymus and activationregulated chemokine and macrophage-derived chemokine. Int Immunol 11:81-88

14. Taub DD, Lloyd AR, Conlon K, Wang JM, Ortaldo JR, Harada A, Matsushima K, Kelvin DJ, Oppenheim JJ 1993 Recombinant human interferon-inducible protein 10 is a chemoattractant for human monocytes and $\mathrm{T}$ lymphocytes and promotes $\mathrm{T}$ cell adhesion to endothelial cells. J Exp Med 177:1809-1814

15. Castro-Rodríguez JA, Holberg CJ, Wright AL, Martinez FD 2000 A clinical index to define risk of asthma in young children with recurrent wheezing. Am J Respir Crit Care Med 162:1403-1406

16. Husby S, Holm NV, Christensen K, Skoy R, Morling N, Petersen PH 1996 Cord blood immunoglobulin $\mathrm{E}$ in like-sexed monozygotic and dizygotic twins. Clin Genet 50:332-338

17. Kaan A, Dimich-Ward H, Manfreda J, Becker A, Watson W, Ferguson A, Chan H, Chan-Yeung M 2000 Cord blood IgE: its determinants and prediction of development of asthma and other allergic disorders at 12 months. Ann Allergy Asthma Immunol $84: 37-42$
18. Sullivan SE, Staba SL, Gersting JA, Hutson AD, Theriaque D, Christensen RD, Calhoun DA 2002 Circulating concentrations of chemokines in cord blood, neonates, and adults. Pediatr Res 51:653-657

19. Mellembakken JR, Aukrust P, Hestdal K, Ueland T, Åbyholm T, Videm V 2001 Chemokines and leukocytes activation in the fetal circulation during preeclampsia. Hypertension 38:394-398

20. Fillion I, Ouellet N, Simard M, Bergeron Y, Sato S, Bergeron MG 2001 Role of chemokines and formyl peptides in pneumococcal pneumonia-induced monocytemacrophage recruitment. J Immunol 166:7353-7361

21. Zhang Y, Luxon BA, Casola A, Garofalo RP, Jamaluddin M, Brasier AR 2001 Expression of respiratory syncytial virus-induced chemokine gene networks in lower airway epithelial cells revealed by cDNA microarrays. J Virol 75:9044-9058

22. Matsukawa A, Hogaboam CM, Lukacs NW, Lincoln PM, Evanoff HL, Kunkel SL 2000 Pivotal role of the $\mathrm{CC}$ chemokine, macrophage-derived chemokine, in the innate immune response. J Immunol 164:5362-5368

23. Terada N, Nomura T, Kim WJ, Otsuka Y, Takahashi R, Kishi H, Yamashita T, Sugawara N, Fukuda S, Ikeda-Ito T, Konno A 2001 Expression of C-C chemokine TARC in human nasal mucosa and its regulation by cytokines Clin Exp Allergy 31:1923-1931

24. Vestergaard C, Bang K, Gesser B, Yoneyama H, Matsushima K, Larsen CG 2000 A Th2 chemokine, TARC, produced by keratinocytes may recruit CLA+CCR4+ lymphocytes into lesional atopic dermatitis skin. J Invest Dermatol 115:640-646

25. Kakinuma T, Nakamura K, Wakugawa M, Mitsui H, Tada Y, Saeki H, Torii H, Asahina A, Onai N, Matsushima K, Tamaki K 2001 Thymus and activation-regulated chemokine in atopic dermatitis: serum thymus and activation-regulated chemokine level is closely related with disease activity. J Allergy Clin Immunol 107:535-541

26. Leung TF, Wong CK, Chan IHS, Ip WK, Lam CWK, Wong GWK 2002 Plasma concentration of thymus and activation-regulated chemokine is elevated in childhood asthma. J Allergy Clin Immunol 110:404-409

27. Leung TF, Ma KC, Hon KL, Lam CWK, Wan H, Li CY, Chan IHS 2003 Serum concentration of macrophage-derived chemokine may be a useful inflammatory marker for assessing severity of atopic dermatitis in infants and young children. Pediatr Allergy Immunol 14:296-301

28. D'Angio CT, Johnston CJ, Wright TW, Reed CK, Finkelstein JN 1998 Chemokine mRNA alterations in newborn and adult mouse lung during acute hyperoxia. Exp Lung Res 24:685-702

29. Johnston CJ, Oberdorster G, Gelein R, Finkelstein JN 2000 Newborn mice differ from adult mice in chemokine and cytokine expression to ozone, but not to endotoxin. Inhal Toxicol 12:205-224

30. Yamamoto C, Kojima T, Hattori K, Nogi S, Imamura H, Tsubura A, Kobayashi Y 1996 Eosinophilia in premature infants: correlation with chronic lung diseases. Acta Paediatr 85:1232-1235

31. Raghavender B, Smith JB 1997 Eosinophil cationic protein in tracheal aspirates of preterm infants with bronchopulmonary dysplasia. J Pediatr 130:944-947

32. Evans M, Palta M, Sadek M, Weinstein MR, Peters ME 1998 Associations between family history of asthma, bronchopulmonary dysplasia, and childhood asthma in very low birth weight children. Am J Epidemiol 148:460-466

33. Elder DE, Hagan R, Evans SF, Benninger HR, French NP 1996 Recurrent wheezing in very preterm infants. Arch Dis Child Fetal Neonatal Ed 74:F165-F171 